\title{
METHOD AND DEVICE FOR MEASURING STABILITY OF PLANT DEVELOPMENT BY FLUCTUATING ASYMMETRY OF OPTICAL DENSITY OF LEAVES
}

\author{
Sergey Rakutko ${ }^{1}$, Elena Rakutko ${ }^{1}$, Ansis Avotins ${ }^{2}$, Peteris Apse-Apsitis ${ }^{2}$ \\ ${ }^{1}$ Institute for Engineering and Environmental Problems in Agricultural Production, Russia; ${ }^{2}$ Riga \\ Technical University, Latvia \\ sergej1964@yandex.ru
}

\begin{abstract}
The purpose of this work is to develop a method for assessing the stability of plant development by using the fluctuating asymmetry of the optical density of plant leaves and to design a device for experimental implementation. The paper reviews existing methods and devices for estimating the fluctuating asymmetry by linear and angular dimensions, where the main disadvantages are the high labour inputs and lack of the required functions. It is shown that the optical densities of half-leaves can act as the bilateral traits, by which the stability of plant development can be assessed. The developed method allows to give a comprehensive assessment of energy and ecological compatibility of indoor plant lighting. The hardware component of the device allows to form the vectors of the radiation fluxes incident and transmitted through the leaf for each leaf half in the blue, green and red spectral bands. The experimental model of the device contains an integrating sphere with a photo resistor, measuring the irradiation of the inner surface. Control program is executed on the Arduino Uno microcontroller board based on the Microchip ATmega328P. The measured data are displayed on LCD screen (Keypad Shield) and stored in the external memory (SD card). Colour LEDs are used as the radiation source. The control program provides calibration modes, measurement of optical density and measurement of fluctuating asymmetry of the optical density in three spectral bands. The device was tested on vegetable marrow plants grown in laboratory conditions under light sources with different light quality. The differences in the optical density and fluctuating asymmetry in separate spectral bands were found to be statistically significant for plants grown under different light sources. The designed device provides wide opportunities for rapid assessment of the plant state by the pigment content in leaves. In the presence of appropriate experimental data, it is possible to find a correlation between the values of the optical density of the leaves and other biometric parameters of the plant.
\end{abstract}

Keywords: indoor plant lighting, leaf, pigments, fluctuating asymmetry, optical density, absorption spectrum.

\section{Introduction}

Application of optical radiation in the indoor plant lighting imposes special requirements on the energy and material resource efficiency. To address the energy saving issue in a comprehensive manner, the concept of the technological process of irradiation is proposed [1]. Environmental factors (such as temperature, irradiation, humidity, etc.) have a great effect on the plant growth and development. Compatibility of the factor levels with required values mirrors plant development stability. Developmental stability is a set of mechanisms, which allows for sustainable development (support of the phenotype) of a living organism despite the changes in environmental conditions or genetic abnormalities [2]. A measure of developmental stability is the fluctuating asymmetry (FA) of bilateral traits. The biometric parameters are usually the linear and angular dimensions, which are measured by a calibrated compass, a ruler and a protractor [3]. The disadvantage of this approach is the time and labour consuming measuring of linear and angular dimensions. In addition, the value of FA, calculated through the geometric dimensions of bilateral structures, fails to characterise adequately the plant developmental stability.

The optical characteristics reflecting the physiological state of plants are more informative in this respect. Thus, the light transmitting ability of leaves directly depends on the pigment content, which to a large extent affects the physiological processes in the plant. One of the most important tasks in biological science is to study the metabolism in the plant body, which determines its growth and development. The main function of plastid pigments is absorption and conversion of solar energy into chemical energy and its accumulation in the form of organic substances in the process of photosynthesis. The leaf absorption of optical radiation energy covers the energy requirements of all physiological processes occurring in the plant. Therefore, investigation of the leaf optical properties makes it possible to reveal the patterns of energy absorption by the plant body and to outline the ways of its rational use [4]. Currently, the structure of absorption spectrum of plant leaves, the issues of environmental and species variability of leaf optical properties are well established $[5 ; 6]$. 
In addition, to study the photosynthetic systems by their optical properties is the best method of non-destructive investigation of plant organisms in vivo. Green plastids play a big role in metabolism. Their hyper responsiveness is stipulated by the protein and lipoid nature of the lamellar - granular structure and the presence of chlorophyll pigments and carotenoids. Along with this, the pigment and enzyme systems of green plastids can take part in other metabolic processes.

The light energy absorbed by chlorophylls is used for carbonic acid reduction and in various biochemical processes, including formation of the cell structure, protein biosynthesis, secondly transformations of carbohydrates, absorption of mineral elements and other processes [7]. Leaf optical properties affect the characteristics of incident radiation absorption, assimilation of flux energy, the intensity of photosynthesis and adaptation processes in plants. Environmental conditions affect the cell geometry, the morphology of assimilation tissues, the content and ratio of main photosynthesis pigments, and the structure of photosynthetic membranes. Assessment of pigment content in plants allows to implement the methods of objective environmental monitoring of indoor plant lighting and to identify the impact factors of various components of growing environment.

Leaf optical characteristics are measured with the use of portable devices, which record the radiation from the LEDs with different spectral bands passing through a leaf [8]. In practice, the CCM200 chlorophyll meter is quite widely used to estimate the chlorophyll content by the LED radiation absorption by the leaf. There is the operational experience of determining the FA of cucumber [9] and tomato [10] leaves grown in indoor plant lighting with this device. Applicability of the DP-1M densitometer to estimate the optical density of a plant leaf was investigated in our study [11]. This device allowed for quick monitoring of the plant state in the process of its growth by the leaf pigment content. Its indoor plant lighting application can contribute to higher crop yields and crop quality. When the relevant experimental data are available, the correlation between the leaf optical density values and other plant biometrics can be found. A more sophisticated instrument is a portable spectrometer that allows to quickly record the absorption spectrum of a leaf [12]. The main disadvantage of these devices is a lack of some important functions - they are not designed to estimate the stability of plant development by an array of paired comparisons of leaf optical properties.

The aim of this study was to develop a method for assessing the plant developmental stability by the fluctuating asymmetry of the leaf optical density and to offer the design of the device for its implementation.

\section{Method for assessing the plant developmental stability by the difference in pigment content}

The method under consideration is developed on provisions of absorption spectroscopy and colorimetry, based on the measurement of the amount of light absorbed by the leaf tissues [13]. When monochromatic light is transmitted through the plant leaf with the initial intensity $I_{\lambda}$, the intensity of the transmitted light decreases to $I_{\lambda}$ due to its partial absorption in the tissues. Following the absorption laws of Bouguer, Lambert and Beer, there is a relationship between the light absorption by the leaf, its thickness $d$ and absorbing substance content $p$ in the tissues expressed by the equation (1):

$$
D_{\lambda}=\varepsilon_{\lambda} p d,
$$

where $\varepsilon_{\lambda}$-absorption coefficient at the wavelength $\lambda$;

$D_{\lambda}$ - leaf optical density at the wavelength $\lambda$.

On the other side, according to formula (2):

$$
D_{\lambda}=\lg \frac{I_{\lambda_{0}}}{I_{\lambda}} .
$$

Thus, by determining the leaf optical density by the fluxes ratio and knowing the leaf thickness and absorption properties of the tissues, it is possible to calculate the content of the light absorbing substance. In our case we can avoid these calculations, as practically the leaf optical density is directly proportional to the content of the absorbing substance, i.e. pigments. In a more general case, it can be written that the optical density in the spectral band $\lambda$ is a function of the pigment concentration, according to formula (3): 


$$
D_{\lambda}=f_{\lambda}(p) .
$$

In practice, it is more convenient to measure radiant fluxes instead of radiation intensities. The incident and transmitted radiant flux for each band are measured twice, on the left and right halves of each $i$-th leaf. Optical density $(D)$ values for the left $(L)$ and right $(R)$ sides of the leaf may be written as in formula (4):

$$
D_{\lambda i}^{L}=\lg \frac{F_{\lambda i_{0}}^{L}}{F_{\lambda i}^{L}}, D_{\lambda i}^{R}=\lg \frac{F_{\lambda i_{0}}^{R}}{F_{\lambda i}^{R}} .
$$

Then the fluctuating asymmetry value computed for each spectral band will be as in formula (5)

$$
F A_{\lambda}=\frac{1}{N} \sum_{i=1}^{N} \frac{\left|D_{\lambda i}^{L}-D_{\lambda i}^{R}\right|}{\left(D_{\lambda i}^{L}+D_{\lambda i}^{R}\right)} .
$$

Thus, the plant developmental stability can be characterised by $F A_{\lambda}$, which, in its turn, depends on the difference in optical density $(D)$ on both sides of the $i$-th leaf.

The reason for the latter is the difference in the pigment content $p_{i}^{L}$ and $p_{i}^{R}$. As a result, the uneven distribution of pigments on symmetric leaf points is interconnected with the indicator of the plant development stability $S$, according to formula (6):

$$
S=f\left(\Phi A_{\lambda}\right)=f\left(f\left(D_{\lambda}^{L}-D_{\lambda}^{R}\right)\right)=f\left(f\left(f\left(p_{i}^{L}\right)-f\left(p_{i}^{R}\right)\right)\right)=f\left(\Delta p_{i}\right) .
$$

The hardware component of the device is to form the vectors of the incident and transmitted through the leaf flows for each half of the leaf in blue $b$, green $g$ and red $r$ spectral bands.

\section{Design and circuit solutions of the device}

The components of the experimental model of the device are arranged in a measurement unit (Fig. 1). The main part is the hollow integrating sphere (spherical photometric integrator, Ulbricht sphere). It is known that, if the inner surface of the sphere is a non-selective diffuse reflector, then its indirect irradiance is directly proportional to the flux incident on the inner surface [14]. The sphere is made of plastic. Its inner surface is coated with the mix of barium sulphate, celluloid and acetone. The entrance opening (port) of the sphere serves for introduction of the flux from the irradiation source (calibration mode), or the flux transmitted through the sample under study (measurement mode). The irradiance of the inner surface is measured by a photo resistor mounted at the exit port of the integrating sphere. To prevent direct irradiation of the photo resistor by LED, a baffle (light barrier) is positioned to separate these ports inside the sphere [15].

To make the coating and assembly easier, two half-spheres are connected with flanges. Irradiation source is mounted on the holding-down clamp in such a way that, when the plant leaf is pressed between the clamp and the integrating sphere with the relevant force, the limit stop switch is triggered, issuing a signal to read the irradiance level. Electrical signals of the measurement unit are directed to the connector. Figure 2 shows the connection schematic: A1 - measurement unit; A2 - Arduino Uno controller board; A3 - digital indicator LCD Keypad Shield, combined with a keyboard unit; A4 external memory card on the SD card. Electronic add-on components are attached to the breadboard.

The device is assembled with standard wires with connectors. The irradiation source consists of the following LEDs: in the blue band - BL-L502UBC, with the radiation peak at $\lambda=470 \mathrm{~nm}$ and the luminous flux of 2-5 cd; in the green band - BL-L502 PGC with the radiation peak at $\lambda=525 \mathrm{~nm}$ and luminous flux of 2-5 cd; in the red band - L-1503 SRC-F with the radiation peak at $\lambda=640 \mathrm{~nm}$ and the luminous flux of $3.5-4.0 \mathrm{~cd}$.

When working in automatic mode, the signal is read from the limit stop switch. When the holding-down clamp is triggered, a high signal level indicates the beginning of measurements. The signals from the photo resistor and the thickness sensor are directed to the Arduino analogue and digital inputs. In accordance with the control programme logic, its digital outputs send the signals to the measuring unit to turn on the colour LEDs. 


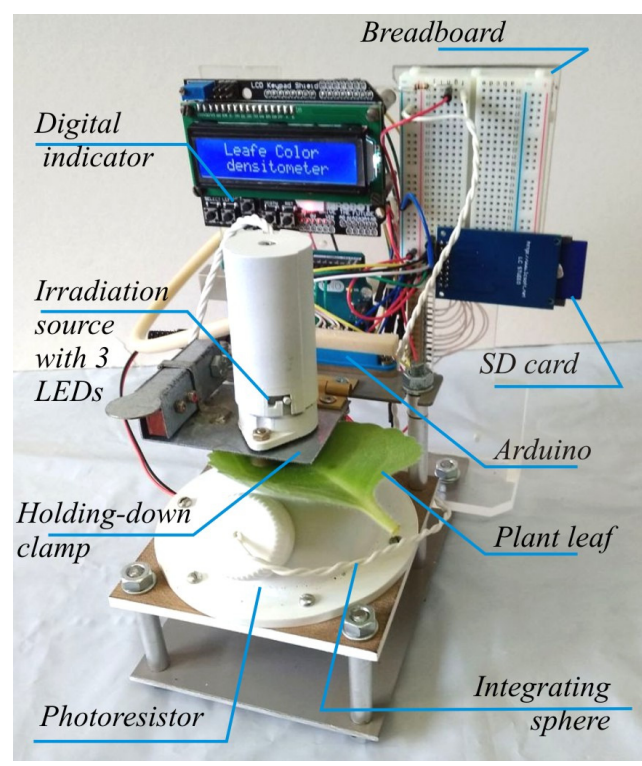

Fig. 1. Measurement unit

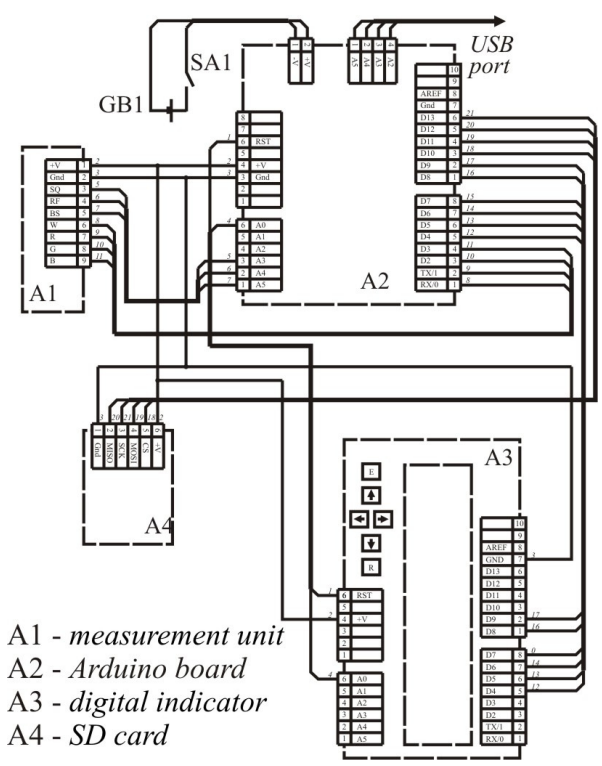

Fig. 2. Connection schematic

\section{Operation algorithm and software}

The control program was created in Arduino IDE programming environment, which is userfriendly in terms of editing and debugging. Standard programme codes (from libraries) "LiquidCrystal.h" and "SD.h" for the LCD display and memory card were used. The control program provided the following algorithm for the device operation. After the power was turned on, the program cycle started.

There were two modes of operation - optical density measurement and fluctuating asymmetry of optical density measurement in three spectral ranges. In the second mode the measurements were carried out twice - on the left and right halves of the plant leaf and the programme computed the FA value. The required mode was set from the keyboard. First of all, the irradiation source was pressed to the entrance port of the integrating sphere. When the limit stop switch was triggered, the program alternately supplied the signals to the corresponding digital outputs to turn on the coloured LEDs. After the readings had stabilized, the signals were read from the photo resistor. The incident fluxes were generated. Then a leaf was placed between the irradiation source and the entrance port of the integrating sphere. Now, when the limit stop switch was triggered, each colour LED was on, and the program measured the flux that had passed through the leaf in the respective spectral band. Optical density and fluctuating asymmetry values were computed for respective spectral bands. The obtained values were displayed on the digital indicator and recorded on the memory card, from where they could be further exported to Excel for statistical processing.

\section{Test results and discussion}

The device was tested on vegetable marrow plants (Cucurbita pepo var. Giromontina) grown under laboratory conditions. Marrow is an herbaceous annual vegetable plant of the Cucurbita (pumpkin) genus. Fresh marrows are used from spring (grown in greenhouses) until the autumn (grown in the open ground). Marrows are light demanding plants; the irradiance level affects their growth parameters and photosynthesis intensity, as is common with all plants [16].

It is known that under low irradiance level the morphological changes maximise the use of light by increasing the surface area of leaves, inter-nodal distances, and reducing the leaf thickness. In addition, the size and chlorophyll content of green plastids also increase [17]. The light quality also has an effect on the plant morphology. The light quality (primarily, blue radiation quantity) was found to influence the leaf thickness and the number of green plastids [18].

Moreover, blue light causes changes in the composition of chloroplasts providing a higher Chl a / $\mathrm{Chl} b$ ratio [19]. Green radiation has a generally positive effect on the plant development [20]. Far-red radiation stimulates an increase in the plant biomass [21]. 
In our study the plants were grown under light sources with different light quality. The spectral composition by bands (blue; green; red; far-red) was as follows:

Light source 1 (LS1): $25 \% ; 24 \% ; 48 \% ; 3 \%$. Light source 2 (LS2): $18 \% ; 22 \% ; 39 \% ; 21 \%$.

The most important spectral differences were that LS 2 had a significantly larger share of far-red flux under reduced flux in blue and red bands. The optic density (OD) of formed cotyledons was measured in plants in the second true leaf phase. A total of 38 plants were grown under each light source. The mean values of the measured parameters and standard deviations for the leaf optical density values are shown in Table 1.

Table 1

Measurement results

\begin{tabular}{|c|c|c|c|c|}
\hline \multirow{2}{*}{ Parameter } & \multicolumn{2}{|c|}{ LS1 } & \multicolumn{2}{c|}{ LS2 } \\
\cline { 2 - 5 } & $\bar{X}$ & $\sigma$ & $\bar{X}$ & $\sigma$ \\
\hline$D_{b}$ & 3.39 & 0.13 & 3.18 & 0.12 \\
\hline$D_{g}$ & 1.36 & 0.09 & 1.27 & 0.08 \\
\hline$D_{r}$ & 2.00 & 0.14 & 1.84 & 0.14 \\
\hline$\Phi A_{b}$ & 0.0136 & - & 0.0224 & - \\
\hline$\Phi A_{g}$ & 0.0248 & - & 0.0333 & - \\
\hline$\Phi A_{r}$ & 0.0267 & - & 0.0267 & - \\
\hline
\end{tabular}

Verification of the optical density value distribution by the tests for concordance of KolmogorovSmirnov, Shapiro-Wilk and Lilliefors showed that the distribution nature of the samples was described by the normal distribution law. With this in mind, the hypothesis on the difference of average values for different light sources was verified by the $t$-test. Calculations showed that the differences in the optical density in the spectral bands are statistically significant for different light sources.

\section{Conclusions}

1. Plant developmental stability can be assessed by the fluctuating asymmetry of the leaf optical density. The developed method allows to include these indicators in the comprehensive assessment of the energy and ecological compatibility of indoor plant lighting.

2. Available portable devices for measuring the optical properties of leaves lack some important functions. The designed device measures the fluxes incident and transmitted through each half of the leaf in blue, green and red spectral bands.

3. The device was tested on vegetable marrow plants grown under laboratory conditions under the light sources with different light quality. It was revealed that the differences in the optical density and fluctuating asymmetry in respective spectral bands are statistically significant for plants grown under different light sources.

4. The designed device can be recommended for application in energy an environmental audit of indoor plant lighting; for rapid assessment of the light source effectiveness and in research.

\section{Acknowledgements}

The publication is created with support of the European Regional Development Fund project "New control methods for energy and ecological efficiency increase of greenhouse plant lighting systems (uMOL)", Grant Agreement Nr. 1.1.1.1/16/A/261.

\section{References}

[1] Ракутько C.A. Оптимизация электротехнологических процессов оптического облучения в АПК (Optimization of electrotechnical processes of optical irradiation in the agro and industrial complex). В сб.: Проблемы и перспективы развития отечественной светотехники, электротехники и энергетики. Саранск, 2008, С. 129-132. (In Russian)

[2] Debat V., David P. Mapping phenotypes: canalization, plasticity and developmental stability. T. Ecol. and Evol. Vol. 16(10), 2001, pp. 555-561. 
[3] Мазуркин П.М., Семенова Д.В. Способ измерения флуктуирующей асимметрии листьев березы (A method for measuring fluctuating asymmetry of birch leaves). Pat. RF №2556987. Publ. 20.07.2015. (In Russian).

[4] Гиллер Ю.Е. О действии некоторых физиологических факторов на оптические свойства листьев растений (On the effect of certain physiological factors on the optical properties of plant leaves). Автореф. дисс. к.б.н. Душанбе, 1964, 26 с. (In Russian).

[5] Леман В.М. Курс светокультуры растений (The course of photoculture of plants). М.: Высшая школа, 1976. (In Russian).

[6] Шульгин И.А. Растение и солнце (Plant and Sun). Л.: Гидрометеоиздат, 1973. (In Russian).

[7] Шиян П.Н. Роль пигментов пластид в обмене веществ растений (The role of plastid pigments in plant metabolism). Автореф. дисс. к.б.н. Киев, 1966, 18 с. (In Russian).

[8] Будаговская О.Н., Козлова И.И., Гончаров С.А. Простое устройство для экспресс-оценки светопропускной способности укрывных материалов в области фотосинтетически активной радиации (A simple device for rapid assessment of the light transmittance of covering materials in the field of photosynthetically active radiation). Pat. RF №156626. Publ. 10.11.2015. (In Russian).

[9] Rakutko S.A., Rakutko E.N., Avotins A., Berzina K. Irradiation level affects fluctuating asymmetry value of bilateral traits of cucumber in juvenile phase. Agronomy Research, vol. 16(3), 2018, pp. 854-861.

[10] Rakutko S.A., Alsina I., Avotins A., Berzina K. Manifestation of effect of fluctuating asymmetry of bilateral traits of tomato growing in industrial greenhouses. Engineering for Rural Development 17th International Scientific Conference. Jelgava, 2018. pp. 186-191.

[11] Ракутько Е.Н., Ракутько С.А. Методика измерения оптической плотности листьев растений с применением денситометра ДП-1М (Methods of measuring the optical density of the leaves of plants using a densitometer DP-1M). Технологии и технические средства механизированного производства продукции растениеводства и животноводства, 2018, № 94, C. 23-35. (In Russian)

[12] CI-710 Miniature Leaf Spectrometer [online] [31.02.2019]. Available at: https://www.cidinc.com.

[13]Гавриленко В.Ф., Жигалова Т.В. Большой практикум по фотосинтезу (Great workshop on photosynthesis). М.: Академия, 2003. 256 c. (In Russian).

[14] Справочная книга по светотехнике (Reference book on lighting). Под ред. Ю.Б. Айзенберга. M., 2008, 952 c. (In Russian)

[15]Эпштейн М.И. Измерение оптического излучения в электронике (Measurement of optical radiation in electronics). М.: Энергоатомиздат, 1990, 254 с. (In Russian).

[16] Wyżgolik, G., Nawara, J., Leja, M. Photosynthesis and some growth parameters of sweet pepper grown under different light conditions. Scientific works of the lithuanian institute of horticulture and lithuanian university of agriculture, vol.27(2), 2008, pp.93-98.

[17] Juan Carlos Diaz-Perez, J.C. Bell Pepper (Capsicum annum L.) Crop as Affected by Shade Level: Microenvironment, Plant Growth, Leaf Gas Exchange, and Leaf Mineral Nutrient Concentration. Hortscience, vol. 48(2), 2013, pp.175-182.

[18] Schuerger A.C., Brown C.S., Stryjewski E.C. Anatomical Features of Pepper Plants (Capsicum annuum L.) Grown under Red Light-emitting Diodes Supplemented with Blue or Far-red Light. Annals of Botany, vol. 79, 1997, pp. 273-282.

[19] Hoffmann A.M., Noga G., Hunsche M. Acclimations to light quality on plant and leaf level affect the vulnerability of pepper (Capsicum annuum L.) to water deficit. Journal of Plant Research, vol. 128(2), 2015, pp. 295-306.

[20] Samuolienė G., Brazaitytė A., Duchovskis P. etc. Cultivation of vegetable transplants using solidstate lamps for the short-wavelength supplementary lighting in greenhouses. Acta Hort, vol. 952, 2012, pp. 885-892.

[21] Brown C.S., Shuerger A.C., Sager J.C. Growth and photomorphogenesis of pepper plants under red light-emitting diodes with supplemental blue or far-red lighting. J Am SocHortic Sci., vol. 120, 1995, pp. 808-813. 